where, to a specifically local problem. 'Thus in Kenya, night screening of cattle from mosquitoes protects them from Rift Valley fever, whoreas in South Africa the vectors are day-biting mosquitoes.

If each local problem requires specific study, then it is important to start in the most promising areas. In East Africa, the forest fringes are such areas. There the species of the forest and the open country come in contact, and there are other species which can only maintain themselves on the forest fringes. But this is only one such 'fringe area'; in Kenya, kala azar is somehow connected with the termite hills which represent another such contact area. Several speakers stressed our ignorance of forest animal ecology and hoped that more work would be done in this field. Others directed attention to the effect of turning pasture land into arable land, and to the effects of new irrigation schemes in East Africa.

One curious feature of the conference was the repeated criticism of the laws of the East African territories. It was pointed out that existing legislation in many fields is extremely advanced and ridiculously at variance with existing practice. The laws cannot, in fact, be enforced, and this has had unfortunate results. In other fields they are curiously restrictive, as was brought out by reference to campaigns against rabies. There is no legislation against laying poison bait, but the officers who lay it are personally financially responsible for any ensuing claim for damages. So much publicity is therefore necessary before laying bait "that even the jackals heard about it", and such campaigns have been extremely ineffective.

The conference revealed the enormous fields for research that the zoonoses hold in East Africa, and in his closing remarks the president, Mr. H. R. Binns, of the East African Veterinary Research Organization, stressed this. He called for the closest cooperation of medical and veterinary research workers and other scientists which has been so fruitful in the past, and emphasized the willingness of all institutions and organizations in East Africa to welcome visiting workers from other countries who wish to help in the solution of East Africa's many problems.

\title{
OBITUARIES
}

\section{Prof. A. O. Rankine, O.B.E., F.R.S.}

THE death, on Januury 20, of Alexander Oliver Rankine at the age of seventy-four removes a much respected figure from scientific circles in London, especially those connected with applied physics. $\mathrm{He}$ played a leading part in the dovelopment of important branches of that subject, including optics and geophysics, not only in their technical aspects but also in connexion with the relevant organizations, both academic and professional. In later years he gave much devoted service to the Royal Institution. $\mathrm{He}$ was a frequent lecturer there, and was honorary secretary during 1945-52.

Born in 1881, he was the son of the Rev. John Rankine, of Guildford, a Baptist minister, and started his education at the Board school at the age of four years. Later on, he attended Guildford Grammar School, whence he won a county major scholarship to University Colloge, London, and graduated with first-class honours in physics in 1904. He was awarded the D.Sc. degree in 1910 for his published work, mostly on the viscosity of gases and associated studies of the dimensions of gaseous molecules.

$\mathrm{He}$ held a research appointment in University College during 1904-19, except for a period in the Admiralty Experimental Station, Harwich, during 1917-18, in which he worked on a method of telephonic communication by the modulation of a beam of light. He was made O.B.E. in 1919. After the First World War he accopted the post of assistantprofessor of physics in the Imperial College of Science and Tochnology, South Kensington, being later promoted to a full professorship. His outstanding personal gifts, generosity and organizing capacity brought him into prominence, and when Prof. F. J. Cheshire (director of the Technical Optics Department) retired in 1925, Rankine was appointed to that post, which he held until 1931, when the Optics Department became a postgraduate branch of the Physics Department under Prof. (now Sir George)
Thomson. About this time he became the last president of the Optical Society.

The great interest in optical research stimulated by the First World War had diminished, and the Optical Society lacked the resources to maintain it as an independent body. Under Rankine's guidance it was united with the Physical Society. (Perhaps the wisdom of this step was not fully apparent until some years later, when the Optical Group of the Physical Society was formed with his help and has continued increasingly to flourish.) Rankine was president of the Physical Society for the first two years after the union. He had always taken a keen interest in that Society as its honorary secretary (1923-29) and member of Council.

He was one of the founder fellows of the Institute of Physics and served on the Board in various offices, including that of honorary secretary and vicepresident during 1923-37; also during 1943-47. His tolerance and level-headed counsel made him a highly valued member of committees, and a large amount of such work fell to his share, including various tasks in connexion with Section A of the British Association, of which he was president in 1932 .

In the early nineteen-thirties, Rankine became interested in the rapidly developing subject of geophysics, and gave much help to the early development of related studies in the Imperial College. Various papers under his name on geophysical instruments were beginning to appear at the time of his election to followship of the Royal Society in 1934 . He left the Imperial College in 1937 to become the chief physicist to the Anglo-Iranian Oil Company, in which capacity he paid several visits to Persia, encountering various adventures which he would describe in his own amusing way. Between 1942 and 1945 he was seconded to the Petroleum Warfare Department, in which connexion he had much to do with the development of 'Fido'-the use for fogdispersal of petroleum vapour burners flanking landing strips on air-fields. A visitor to Earl's Court on a wintry day might find Rankine and his assistants 
wrapped in duffle-coats and working cheerfully in icy cavornous gloom with giant fans, rows of burners on the floor, and arrays of eloctrical thermometers to record the three-dimensional temperature distribution. It was a task for which his oarlier researches on the viscosity of air had prepared him very well.

After service as visitor and manager, he was appointed in 1945 honorary secretary of the Royal Institution, a post which was to involve him, a few years later, in acutely controversial personal issues. Few will be disposed to deny the courage and tenacity with which he successfully maintained his position and views in the face of increasing difficulties and deteriorating health. The key to his general position on social issues lay in his early upbringing, and an instinct to support humbler ones against power and privilege. He had, as he said, a natural sympathy with the rebel, though he took his place easily and naturally in any milieu. His rare gift of friendship will make his loss widely mourned.

He married, in 1907, Ruby Irene, daughter of the late Mr. Samuel Short, of Reading, and had two sons and two daughters.

L. C. Martin

\section{Dr. A. L. Hall, F.R.S.}

Arthur Lewis Hall, one of the foremost contributors to South African geology, died on August 13, 1955, at his home in Pretoria.

Hall was born on January 10, 1872, at Birmingham. A scholar of Gonville and Caius College and Harkness Scholar in geology at Cambridge, where later he also took his doctorate, he was appointed field geologist to the Geological Survey of the Trans. vaal in 1903. In 1915 he became assistant director of the Geological Survey of the Union of South Africa and in January 1932, on reaching the age limit, he retired from official duties after thirty years of devoted service to the Stato and to South African geology. He then busied himself as a consulting geologist, until his eyes began to trouble him and he was forced to withdraw from further active work in the profession in which he took such a lively interest and achieved so much.

Apart from general features, little was known of the geology of the Transvaal in 1903. Consequently, almost wherever his work led him, Hall found himself breaking fresh ground, and he can justly be counted among the able pioneers of South African geology. Most of his work was done in the eastern and northeastern Transvaal in a much diversified country of rugged mountains and low-lying bush-veld. In the early days, field-work there was accompanicd by many obstacles as well as a vast amount of fatiguing work that called for ingenuity, courage and the ability to overcome difficulties in order to achieve success. Hall, a great enthusiast and an energetic worker, possessed these qualities to a marked degree. His strong constitution and tenacity of purpose enabled him to produce the fine geological maps for which he is noted.

By his strenuous field-work, his detailed microscopical studies of large amounts of petrological material and other research work, Hall was able to make many important contributions to geology in the fields of pure as well as applied science, and thus exerted a lasting influence on geological development over a wide part of the Transvaal. He will be especially remembered for the leading part he played in the delineation of the Transvaal System and its relationships to other formations, his studies of the
Archæan formations, his investigations of the country's mineral resources and, above all, his elucidation of that great igneous assemblage known as the Bushveld Igneous Complex, with its wide, contact metamorphic aureole. $\mathrm{He}$ conducted the Shaler Momorial Fxpedition and also the Bushveld excursion of the International Geological Congress through the northern and eastern parts of the Complex, when he was able to present "much important field-evidence to a phalanx of geologists that included the élite of international petrographical thought".

International geology was advanced by Hall's share in the deliberations during the sessions of the International Geological Congress hold in Spain, the United States and Russia. The success of the Congress in South Africa in 1929, of which he was the secretarygeneral, was largely due to his organizing abilities.

The Geological Museum of the Geological Survey owes a very large part of its utility and attractiveness to his energy and care.

Hall was a past-president of the Geological Society of South Africa, a Fellow of the Royal Society of South Africa and of the Geological Society of London, a council member and president of the South African Geographical Society, a corresponding member of the Geological Society of America, and a regional vicepresident of the Society of Economic Geologists, United States of America. His distinguished services to geology were recognized by his election as a Fellow of the Royal Society and as an honorary member of the Geological Society of South Africa, and in the award to him by the Geological Society of London of the Murchison Medal, and by the Geological Society of South Africa of the Draper Medal.

Socially, Hall was a man of distinct personality whose sterling worth and ability aroused the deepest respect and admiration among those who worked with him. He will be remembered as much for his intense humanity as for his geological prowess.

LoUIS 'I'. NEL

\section{Dr. E. C. S. Megaw, M.B.E.}

By the sudden death of Dr. E. C. S. Megaw on January 25 at the early age of forty-eight, the nation has lost one of its most prominent scientists in the field of applied radio-physics.

Eric Christopher Stanley Megaw, the eldest son of a Belfast solicitor, was educated at Campbell College and The Queen's University, Belfast; and, after obtaining his B.Sc. degree in electrical engineering, he was elected to a research fellowship at the Imperial College of Science and Technology, University of London. While still a schoolboy, he becamo prominent among radio amateurs, and was reputed to be the first amateur in Ireland to receive signals from New Zealand on his home-made apparatus.

It was at the Imperial College that his scientific interest in the generation and use of very short radio waves was aroused; and, under the direction of Prof. C. L. Fortescue, he studied electronic oscillations in valves. He joined the staff of the Research Laboratories of the General Electric Co., Ltd., in 1930, and rapidly acquired a reputation as a result of his research on the magnetron short-wave oscillator. A paper on this subject read before the Radio Section of the Institution of Electrical Engineers in 1933 was awarded the Duddell Premium of the Institution. He also received the diploma of the Imperial College and later the D.Sc. degree of Belfast. 